\section{DESCRIPTION OF THE COMPLEXITY OF PRESCRIBED MEDICATION REGIMENS IN PRIMARY HEALTH CARE OF RIBEIRÃO PRETO - SP}

\author{
Maria Olívia Barboza Zanetti ${ }^{1}$, Jaqueline Lessa de Moraes $^{2}$, \\ Juliana Maldonado Marchetti ${ }^{1}$, Regina Célia Garcia de Andrade ${ }^{1}$
}

\begin{abstract}
Introduction: Pharmacotherapy is the main therapeutic resource for the management of diseases. However, the number of drugs prescribed, dose frequency, and mode of administration can make the treatment more complex and influence treatment outcomes. The aim of this study was to measure the complexity of prescribed medication regimens in primary health care (PHC) services in Ribeirão Preto, Brazil.
\end{abstract}

Methods: This cross-sectional study included 1,009 participants: 889 from primary health units and 120 from family health units in Ribeirão Preto, Brazil. Treatment complexity was assessed using the Medication Regimen Complexity Index (MRCl).

Results: $\mathrm{MRCI}$ mean scores were 12.5 points $(\mathrm{SD}=9.3)$ and dose frequency was the major contributor to increase the score. The complexity of pharmacotherapy showed a significant correlation with the number of prescribed medications $(r=0.93, p<0.01)$, but not with patients' age $(r=0.28, p<0.01)$. There is also no difference in complexity between the sexes $(p=0.83)$ and the types of primary health care service $(p=0.31)$. An analysis of variance revealed that patients with lower levels of education receive more complex prescriptions $(p<0.01)$.

Conclusions: The pharmacotherapy prescribed in PHC services from Ribeirão Preto, Brazil is complex, and there is a need to concentrate efforts and adopt strategies to simplify drug prescription without compromising patient's clinical status.

Keywords: Primary health care; drug prescriptions; drug therapy; medication regimen complexity

Medications are certainly essential for managing the health-disease process. Drug therapy is the main therapeutic resource to cure and control diseases, but medication use is not exempt from risks and may lead to Drug Realted Problems (DRP) ${ }^{1-3}$.

Currently, the use of multiple medications is a multifactorial problem involving the growing development of new medications and health technologies, the power of marketing promoted by the pharmaceutical industry, the presence of a culture of medicalization in health professional training, and population demand for drug consumption and self-medication ${ }^{2,4}$. In addition, the worldwide epidemiological profile has been changing over the years, resulting in population's aging and consequently in the predominance of non-communicable chronic health conditions and in sequelae arising from the aging process, which in turn increase the need for multiple treatments ${ }^{5}$. The simultaneous use of several medications by the same individual is known as polypharmacy, a practice that exposes patients to higher complexity therapies and increases the risk for $\mathrm{DRP}^{6}$.

Some components of therapeutic regimens, such as number of prescribed drugs, dose frequency, and administration instructions, have an influence on treatment outcomes ${ }^{7}$. This is because these factors make drug administration
Clin Biomed Res. 2018;38(1):1-7

1 Departamento de Ciências Farmacêuticas, Faculdade de Ciências Farmacêuticas de Ribeirão Preto, Universidade de São Paulo (USP). Ribeirão Preto, SP, Brasil.

2 Departamento de Enfermagem Fundamental, Escola de Enfermagem de Ribeirão Preto, Universidade de São Paulo (USP). Ribeirão Preto, SP, Brasil.

Corresponding author:

Maria Olivia Barboza Zanetti

maria.zanetti@usp.br

Departamento de Ciências

Farmacêuticas, Faculdade de Ciências Farmacêuticas de Ribeirão Preto, Universidade de São Paulo (USP)

Avenida do Café, sn.

14040-903, Ribeirão Preto, SP, Brasil. 
a costly, time consuming, and complicated activity, thus increasing treatment complexity and hindering its compliance. Moreover, increased prescription complexity raises susceptibility to drug interactions, adverse reactions, development of comorbidities, and decreased quality of life ${ }^{8}$. Thus, the complexity of the prescribed treatment may influence its adherence ${ }^{9-11}$.

The investigation of drug therapy complexity enables health professionals to estimate the ease (or difficulty) in treatment adherence, to determine the elements that most contribute to increased complexity, and to implement strategies to address these elements and simplify therapy ${ }^{2,11,12}$.

The aim of the present study was to measure the complexity of drug therapy prescribed to patients treated by primary health care $(\mathrm{PHC})$ services in the city of Ribeirão Preto, Brazil, in order to determine the complexity profile of patients' prescriptions and identify the main factors that contribute to increase treatment complexity.

\section{METHODS}

This was a descriptive cross-sectional study conducted in the city of Ribeirão Preto, Brazil, from September 2014 to April 2015. The study was approved by the institution's Research Ethics Committee.

Sample size was calculated by stratified sampling ${ }^{13}$. Health facilities were grouped into eight strata according to health district and to primary health care provided (primary care unit [PCU] or family health unit [FHU]). This strategy allowed for the recruitment of a heterogeneous but representative sample.

A confidence coefficient of $95 \%$ and an absolute accuracy of $3 \%$ were considered for ratio estimation. In order to maximize variance, this ratio was established as $50 \%$ in each stratum, yielding an estimated sample size of 1,052 subjects. Sample allocation was proportional to the mean number of medical appointments/month in each stratum. Two PCUs and two FHUs of each stratum were randomly drawn for data collection; thus, ten UBS and five USF were selected to participate in the research (some health districts did not contain FHU).

Participants' eligibility criteria were: age 18 or older; attendance to the public health system in Ribeirão Preto, considering PCUs and FHUs; being prescribed with at least one medication. This study excluded individuals unable to communicate appropriately, those who were prescribed in the private health insurance system or whose prescriptions lacked dosage for one or more medications.

Participants were selected by non-probability sampling. Public health users were approached while they were waiting for drug dispensing at the
PCU/FHU pharmacy or after medical appointment if the unit did not have a community pharmacy. The participants authorized researchers to make a copy of drug prescription and provided sociodemographic information.

The complexity of the prescribed drug therapy was assessed using the Medication Regimen Complexity Index $(\mathrm{MRCl})^{2}$, an instrument that was translated and validated into Portuguese and are based on the actions required to administer medications. The $\mathrm{MRCl}$ is grouped into three sections:

- Section A: information on dosage forms;

- Section B: information on dose frequency;

- Section C: additional information that the patient should take into consideration for the appropriate drug administration, such as drug specific time, concomitant use with food, drug dissolution in water ${ }^{2}$.

Each section is scored based on treatment complexity (the higher the score, the higher the complexity) and the overall complexity index is obtained by adding the scores of the three sections for each prescribed $\mathrm{drug}^{2}$.

Prescriptions that lacked drug dosage for at least one medication (prescription error) were excluded from calculation. Polypharmacy was characterized according to the criteria established by Lucchetti et al. ${ }^{6}$ as the concomitant use of five or more medications.

Data were codified and stored in a Microsoft Office Excel ${ }^{\circledR} 2007$ spreadsheet and information was entered twice to analyze consistency. Statistical analyses were conducted using the Statistical Analysis System (SAS) software, considering a significance level of $\alpha=0.05$ and a confidence interval of $95 \%(95 \mathrm{Cl})$.

\section{RESULTS}

Of the collected drug prescriptions, 43 lacked drug dosage for at least one medication and were thus excluded from the study. Hence, below are results for the drug therapy complexity of 1,009 prescriptions, of which 889 came from PCUs and 120 from FHUs.

\section{Sociodemographic Characteristics}

Among the participants, $76.8 \%$ were female, and mean age was 54.1 years (standard deviation [SD] = 17.4). There was a predominance of subjects with white skin $(73.5 \%)$ and low educational level, since more than $50 \%$ of participants did not conclude primary education. One of the main criteria to define poverty in Brazil establishes that an individual is considered poor if his/her per capita income is equal to or lower than half minimum wage ${ }^{14}$. According to this definition, 
$27.3 \%$ of our sample is poor. Mean monthly per capita income was BRL 701.37.

Table 1 presents the sociodemographic characteristics of the population studied.

\section{Complexity of the Prescribed Drug Therapy}

Mean scores for drug therapy complexity was 12.5 points $(S D=9.3)$, with a maximum of 67.5 and a minimum of 2.0 points (Table 2 ).

Table 1: Sociodemographic characteristics of the population studied.

\begin{tabular}{|c|c|c|}
\hline Variable & $\mathbf{n}$ & $\%$ \\
\hline \multicolumn{3}{|l|}{ Sex } \\
\hline Male & 234 & 23.2 \\
\hline Female & 775 & 76.8 \\
\hline \multicolumn{3}{|l|}{ Age (years) } \\
\hline $18-40$ & 256 & 25.4 \\
\hline $41-60$ & 327 & 32.4 \\
\hline$>60$ & 426 & 42.2 \\
\hline \multicolumn{3}{|l|}{ Skin color (ethnicity) } \\
\hline White & 742 & 73.5 \\
\hline Black & 108 & 10.7 \\
\hline Asian descent & 6 & 0.6 \\
\hline Mixed race $\dagger$ & 153 & 15.2 \\
\hline Native Brazilian & 0 & 0 \\
\hline \multicolumn{3}{|l|}{ Educational level } \\
\hline Never attended school & 54 & 5.4 \\
\hline Incomplete elementary school & 470 & 46.6 \\
\hline Complete elementary school & 171 & 16.9 \\
\hline Incomplete high school & 82 & 8.1 \\
\hline Complete high school & 173 & 17.1 \\
\hline Incomplete higher education & 23 & 2.3 \\
\hline Complete higher education & 33 & 3.3 \\
\hline Graduate degree & 3 & 0.3 \\
\hline \multicolumn{3}{|l|}{ Per capita income } \\
\hline Below $500 \mathrm{BRL}$ & 427 & 42.3 \\
\hline Below $1,000 \mathrm{BRL}$ & 437 & 43.3 \\
\hline Below $1,500 \mathrm{BRL}$ & 99 & 9.8 \\
\hline Above $1,500 \mathrm{BRL}$ & 46 & 4.6 \\
\hline \multicolumn{3}{|l|}{ Occupational status } \\
\hline Has a job & 345 & 34.2 \\
\hline Works and studies & 12 & 1.2 \\
\hline Retired or pensioner & 388 & 38.5 \\
\hline Unemployed & 33 & 3.3 \\
\hline Studies & 4 & 0.4 \\
\hline Not employed & 227 & 22.5 \\
\hline \multicolumn{3}{|l|}{ Marital status } \\
\hline Single & 165 & 16.4 \\
\hline With a partner & 559 & 55.4 \\
\hline Divorced/separated & 118 & 11.7 \\
\hline Widowed & 167 & 16.6 \\
\hline Total & 1,009 & 100 \\
\hline
\end{tabular}

Table 3 shows the distribution of drug prescriptions according to complexity scores, revealing that nearly the half of the collected prescriptions have a complexity index above 10 points.

As for index sections, it was found that section $B$ (dose frequency) was the major contributor to increase drug therapy complexity, whereas section $A$ (dosage form) was the one that less contributed to this increase (Table 4).

Student $t$ tests were conducted to compare mean complexity scores obtained in PCUs and FHUs, either overall scores and those of each section. No differences were observed in $\mathrm{MRCl}$ scores between the two primary health care models (Table 4 ).

The most prescribed dosage form was capsules/tablets, followed by liquid formulations. The most common dose frequency was "once daily", followed by "every 12 hours". The most provided additional information was "taking/using the medication at a specific time" and "relation to food".

A total of 3,838 medications were prescribed in the 1,009 prescriptions analyzed, yielding in a average of four medications per prescription ( $S D=2.8$ ). Among study participants, $33.3 \%$ were receiving polypharmacy. The relationship between number of medications and treatment complexity was assessed using the Pearson's correlation coefficient. This assessment yielded an $r$ of 0.93 ( $p<0.01$ ); thus, there was a very strong positive correlation between number of medications and drug therapy complexity. Based on these data, it is possible to assume that the higher the number of medications, the higher the complexity of treatment.

The highest complexity score (67.5 points) was obtained by one of the participants with the highest number of prescribed medications $(n=20)$. Similarly, the lowest complexity score (two points) was also proportional to the lowest number of medications

Table 2: Results for complexity analysis of drug prescriptions.

\begin{tabular}{lccc}
\hline & $\begin{array}{c}\text { Primary } \\
\text { care units }\end{array}$ & $\begin{array}{c}\text { Family } \\
\text { health } \\
\text { units }\end{array}$ & Total \\
\hline $\begin{array}{l}\text { Number of medical } \\
\text { prescriptions }\end{array}$ & 889 & 120 & 1,009 \\
$\begin{array}{l}\text { Range of } \mathrm{MRCI} \text { in } \\
\text { the sample }\end{array}$ & 65.5 & 45.0 & 65.5 \\
MRCI mean score & 12.6 & 11.8 & 12.5 \\
$\begin{array}{l}\text { MRCI minimum } \\
\text { score }\end{array}$ & 2.0 & 2.0 & 2.0 \\
$\begin{array}{l}\text { MRCI maximum } \\
\text { score }\end{array}$ & 67.5 & 47.0 & 67.5 \\
\hline $\begin{array}{l}\text { SD: standard deviation; } \\
\text { index. }\end{array}$ & & & \\
\hline
\end{tabular}


Table 3: Drug prescriptions from the primary health care system in Ribeirão Preto, Brazil, grouped according to drug therapy complexity.

\begin{tabular}{|c|c|c|c|c|c|c|}
\hline \multirow{2}{*}{ MRCI score } & \multicolumn{2}{|l|}{ Primary care units } & \multicolumn{2}{|c|}{ Family health units } & \multicolumn{2}{|l|}{ Total } \\
\hline & No. of prescriptions & $\%$ & No. of prescriptions & $\%$ & No. of prescriptions & $\%$ \\
\hline$<5$ points & 172 & 19.3 & 19 & 15.8 & 191 & 18.9 \\
\hline $5.5-10$ points & 273 & 30.7 & 49 & 40.8 & 322 & 31.9 \\
\hline $10.5-15$ points & 193 & 21.7 & 23 & 19.2 & 216 & 21.4 \\
\hline $15.5-30$ points & 207 & 23.3 & 23 & 19.2 & 230 & 22.8 \\
\hline $30.5-45$ points & 34 & 3.8 & 5 & 4.2 & 39 & 3.9 \\
\hline$>45$ points & 10 & 1.1 & 1 & 0.8 & 11 & 1.1 \\
\hline Total & 889 & 100 & 120 & 100 & 1,009 & 100 \\
\hline
\end{tabular}

MRCI: Medication Regimen Complexity Index.

Table 4: Results for the analysis of each section of the Medication Regimen Complexity Index (MRCl).

\begin{tabular}{|c|c|c|c|c|c|c|c|c|c|c|c|c|c|}
\hline & \multicolumn{4}{|c|}{ Primary care units } & \multicolumn{4}{|c|}{ Family health units } & \multicolumn{4}{|c|}{ Total } & \multirow{2}{*}{$\frac{\text { p-value }}{P}$} \\
\hline & Mean score & SD & Min & Max & Mean & SD & Min & Max & Mean & SD & Min & Max & \\
\hline Sectio & 2.3 & 2.0 & 1.0 & 15.0 & 2.1 & 2.1 & 1.0 & 15.0 & 2.3 & 2.0 & 1.0 & 15.0 & 0.48 \\
\hline Section B & 6.2 & 5.0 & 0.0 & 23.0 & 5.9 & 4.3 & 0.0 & 17.0 & 6.2 & 5.0 & 0.0 & 23.0 & 0.44 \\
\hline Section C & 4.1 & 3.6 & 0.5 & 30.5 & 3.8 & 3.1 & 1.0 & 23.0 & 4.1 & 3.6 & 0.5 & 30.5 & 0.24 \\
\hline Total MRCI & 12.6 & 9.4 & 2.0 & 67.2 & 11.8 & 8.3 & 2.0 & 47.0 & 12.6 & 9.4 & 2.0 & 67.2 & 0.31 \\
\hline
\end{tabular}

p-values for Student's t-tests to compare means for primary care units and family health units; SD: standard deviation; Min: minimum; Max: maximum; Section A: information on dosage forms; Section B: information on dosage frequency; Section C: additional information that the patient should take into consideration for the appropriate drug administration; MRCl: Medication Regimen Complexity Index.

$(n=1)$. These findings confirmed the previously found correlation between number of medications and complexity scores. However, there were differences in $\mathrm{MRCl}$ scores between patients using the same number of medications, which demonstrates the significance of other factors in the calculation of the index. $\mathrm{MRCl}$ mean scores and their dispersion measures, considering a 95\% confidence interval, show an overlap of results (Table 5), which confirms that treatments with the same number of medications may have different levels of complexity. It can also be observed that dispersion increase with the increase in the number of medications.

The relationship between participants' age and prescription complexity as assessed by the Pearson's correlation coefficient yielded an r of $0.28(p<0.01)$. This value evidences a negligible correlation, i.e., it is not possible to state that treatment complexity increases with age. Complexity scores were similar across different ages.

With regard to sex, $\mathrm{MRCl}$ mean scores were 12.4 points $(S D=7.9)$ for males and 12.6 points $(S D=9.6)$ for females. According to the Student $t$ test, no differences were observed in drug therapy complexity between the sexes $(p=0.83)$.

The ANOVA test yielded a $p$-value of $<0.01$ for the association between participants' educational level and $\mathrm{MRCl}$ scores, suggesting that variance for complexity is different across the educational levels. Post hoc comparisons were required to investigate
Table 5: Number of medications and drug therapy complexity.

\begin{tabular}{cccc}
\hline $\begin{array}{c}\text { No. of } \\
\text { medications }\end{array}$ & $\mathbf{n}$ & $\begin{array}{c}\text { MRCI mean } \\
\text { score }\end{array}$ & $\mathbf{9 5 \%} \mathbf{C l}$ \\
\hline 1 & 215 & 4.2 & $2.5-5.9$ \\
2 & 210 & 7.4 & $5.1-9.7$ \\
3 & 146 & 10.3 & $7.3-13.3$ \\
4 & 116 & 12.5 & $9.2-15.8$ \\
5 & 99 & 16.1 & $11.9-20.3$ \\
6 & 62 & 17.9 & $14.3-21.5$ \\
7 & 56 & 21.3 & $16.9-25.7$ \\
8 & 34 & 24.2 & $18.8-29.6$ \\
9 & 29 & 29.1 & $22.8-35.4$ \\
10 & 14 & 32.5 & $27.9-37.1$ \\
11 & 9 & 35.9 & $29.8-42.0$ \\
12 & 6 & 34.6 & $29.6-39.5$ \\
13 & 4 & 47.2 & $40.8-53.6$ \\
14 & 2 & 44.0 & $37.6-50.4$ \\
15 & 3 & 59.2 & $55.6-62.8$ \\
16 & 1 & 53.0 & - \\
17 & 1 & 58.0 & - \\
20 & 2 & 57.2 & $42.7-71.7$ \\
Total & 1,009 & 12.5 & $3.2-21.8$ \\
\hline
\end{tabular}

95\%Cl: 95\% confidence interval; MRCl: Medication Regimen Complexity Index.

differences between each pair of educational level groups. Thus, the Tukey test revealed differences between all pairs of educational level groups, except between the high school education group and the higher education group. 


\section{DISCUSSION}

The high prevalence of women at PHC services is a recurrent finding in scientific publications ${ }^{15-18}$, probably because women are knowingly more attentive to disease signs and symptoms and seek health services more often ${ }^{15,19}$.

The high prevalence of elderly in $\mathrm{PHC}$ services is also a common finding, since this population suffers from chronic health conditions and uses a great number of medications ${ }^{5,20}$.

Low socioeconomic level is a remarkable characteristic of our sample, as shown by the low income and low educational level observed in this study. The percentage of the Ribeirão Preto population considered as poor is $11.32 \%{ }^{14}$, whereas $27.3 \%$ of our study population was classified as poor. This was an expected finding, because the present study excluded private health care users. The Brazilian Unified Health System (UHS) was designed exactly to provide health coverage to the poorest populations and reducing health service inequality ${ }^{5}$.

In reviewing the literature, no data was found on $\mathrm{MRCl}$ cut off points for high or low complexity prescriptions. However, the $\mathrm{MRCl}$ mean scores obtained in the present study was different from that of other studies assessing PHC patients, which found lower complexity scores. $\mathrm{MRCl}$ mean scores were 7.4 points in the study by Aldrigue et al. ${ }^{21}$ and 7.7 points in the study by Fröhlich ${ }^{22}$. Our mean values were similar to that found by Obreli-Neto et al. et al. in a research that analyzed only elderly patients (13 points) ${ }^{23}$ who knowingly use a greater number of medications, due to their multiple diseases, chronic conditions, and physiological changes ${ }^{23}$. However, the present study did not find a correlation between prescription complexity and participants' age; hence, it is not possible to state that our high $\mathrm{MRCI}$ mean score may be explained by the great number of elderly included in the sample.

Although $\mathrm{MRCl}$ scores were not significantly affected by age and sex, low educational level was indeed associated with more complex therapies. The same finding was observed by Acurcio et al. in Belo Horizonte, Brazil|11. This may suggest that users with lower income and educational level have worse health conditions, resulting in more complex prescriptions and increased vulnerability to complications resulting from treatment complexity ${ }^{11}$.

It is worth noting that higher $\mathrm{MRCl}$ scores may be related to a high mean number of medications, since there is evidence that $\mathrm{MRCl}$ scores increase with the increase in the number of medications.

The average of four prescribed medications is higher that the number recommended by the World
Health Organization, which defines that a mean number from 1.3 to 2.2 medications do not represent a trend towards polypharmacy ${ }^{24}$. Mean values obtained in studies conducted in PHC services in other Brazilian municipalities were much lower those reported in the present study, ranging from 1.8 to 2.5 medications $^{22,25-28}$; therefore, a trend towards polypharmacy was found in $\mathrm{PHC}$ services in Ribeirão Preto. This is a concerning finding, because polypharmacy may increase drug therapy complexity and create a barrier to treatment adherence ${ }^{6,27}$.

It should also be noted that $33.3 \%$ of our study participants received polypharmacy. This value may be underestimated, since some studies established different definitions for polypharmacy ${ }^{6}$, with cutoffs as low as two or more medications, or divided polypharmacy into classes, such a minor polypharmacy (use of two to four medications) and major polypharmacy (use of five or more medications) ${ }^{29,30}$. Our criterion of choice for polypharmacy was use of five medications or more because we believe that the use of multiple drugs is often required and is beneficial for the treatment of individuals with several comorbidities; thus, the criteria for polypharmacy should not be so strict. Nevertheless, it is essential to avoid the use of multiple medications as much as possible, since polypharmacy compromise patient's safety, increases prescription complexity, and predisposes to the occurrence of drug interactions and adverse events ${ }^{8}$

Although the correlation between number of medications and treatment complexity has already been demonstrated, there is also evidence that treatments with the same number of medications may have different levels of complexity, which corroborates the idea that the number of medications is not the only responsible for treatment complexity. Dosage form, dose frequency, and other additional information should also be taken into account ${ }^{2,7}$.

Consistent with the literature ${ }^{22,31}$, this research found that dose frequency was the $\mathrm{MRCl}$ section that most contributed to drug therapy complexity, thus revealing that frequency of drug administration is equally important as the number of medications, because increased dose frequency enhances patients' forgetfulness and the occurrence of medication errors ${ }^{2}$.

It may be hypothesized that the scores obtained in the additional information section of the instrument may be higher UHS users compared with private health care users; however, no studies have confirmed this hypothesis. This possibility may be explained by the restricted number of options in terms of doses and formulations provided in the lists of medications available in the UHS, which, in some situations, leads to the prescription of multiple doses of the 
same medication at the same time, use of alternate doses, or splitting or dissolving pills.

Strategies should be adopted to reduce the number if daily doses and decrease drug therapy complexity without limiting the use of medications essential to treat patient's disease. A possible strategy is prescribing extended-release medications and medications composed of two or more drugs, whenever available. It is important to demand the inclusion of this type of medication and of different dosage forms and dose options in the lists of essential medicines. Prescriptions should also be reassessed to evaluate the possibility of reducing dose frequency or the number of medications, according to patient's disease and clinical status. Along with physicians, pharmacists are the most skilled professionals to assist in the implementation of these strategies, because they can provide valuable information for drug therapy and patient care and can also manage complex therapeutic regimens, detect and prevent DRP, reduce medication errors, and monitor treatment adherence ${ }^{1,32}$.

The complexity of the therapeutic regimens prescribed in FHUs is similar to that of regimens prescribed in PCUs. Treatment complexity seems to be more associated with characteristics of patients and drugs than with type of PHC service. However, the more comprehensive and humane care proposed by the Family Health Strategy may contribute to patient's understanding of treatment and to rational drug management. Therefore, the health care team and users should be constantly in contact both before and during treatment so that patients can understand the importance of correct use of drugs ${ }^{32}$.

This study does not include medications prescribed by other levels of care or over-the-counter drugs. Hence, treatment complexity may be even greater.

The $\mathrm{MRCI}$ have proved useful for the overall assessment of drug prescriptions and for the identification and analysis of the factors that determine therapy complexity, because this index yields a quantitative measure of the components that may compromise pharmacotherapy adherence. Drug prescriptions to PHC users in Ribeirão Preto, Brazil, are complex compared with those of other municipalities, which may cause DRP and hinder treatment adherence. Health care professionals should concentrate efforts on implementing strategies to simplify the treatment of $\mathrm{PHC}$ users without compromising their clinical status.

\section{Conflicts of Interest}

The authors declare no conflicts of interest.

\section{REFERENCES}

1. Portela AS, Simões MOS, Fook SML, Montenegro AN No, Silva PCD. Prescrição médica: orientações adequadas para o uso de medicamentos? Cien Saude Colet. 2010;15:3523-8.

2. Melchiors AC, Correr CJ, FernándezLlimos F. Tradução e validação para o português do Medication Regimen Complexity Index. Arq Bras Cardiol. 2007;89:210-8.

3. Hepler CD, Strand LM. Opportunities and responsibilities in pharmaceutical care. Am J Hosp Pharm. 1990;47:53343.

4. Secoli SR. Polifarmácia: interações e reações adversas no uso de medicamentos por idosos. Rev Bras Enferm. 2010;63:136-40.

5. Mendes EV. O cuidado das condições crônicas na atenção primária à saúde: o imperativo da consolidação da estratégia da saúde da família. Brasília: Organização Pan-Americana de Saúde; 2012.
6. Lucchetti G, Granero AL, Pires SL, Gorzoni ML. Fatores associados à polifarmácia em idosos institucionalizados. Rev Bras Geriatr Gerontol. 2010;13:51-8.

7. George J, Phun YT, Bailey MJ, Kong DC, Stewart K. Development validation of the medication regimen complexity index. Ann Pharmacother. 2004;38:1369-76.

8. Fröhlich SE, Zaccolo AV, Silva SL, Mengue SS. Association between drug prescribing and quality of life in primary care. Pharm World Sci. 2010;32:744-51.

9. Fröhlich SE, Vigo A, Mengue SS. Association between the morisky medication adherence scale and medication complexity and patient prescription knowledge in primary health care. Lat Am J Pharm. 2011;30:1348-54.

10. Pollack M, Chastek B, Williams SA, Moran J. Impact of treatment complexity on adherence and glycemic control: an analysis of oral antidiabetic agents. J Clin Outcomes Manag. 2010;17:257-65.

11. Acurcio FA, Silva AL, Ribeiro AQ, Rocha NP, Silveira MR, Klein $\mathrm{CH}$, et al. Complexidade do regime terapêutico prescrito para idosos. Rev Assoc Med Bras. 2009;55:468-74.

12. Leite SN, Vasconcellos MPC. Adesão à terapêutica medicamentosa: elementos para a discussão de conceitos e pressupostos adotados na literatura. Cien Saude Colet. 2003;8:775-82.

13. Scheaffer RL, Mendenhall W, Ott $\mathrm{RL}$, Gerow KG. Elementary survey sampling. Boston: Brooks/Cole: Cengage Learning; 2011.

14. Instituto Brasileiro de Geografia e Estatística (IBGE). Estimativas populacionais para os municípios e para as Unidades da Federação brasileiros com data de referência em $1^{\circ}$ de julho de 2015. Brasília: IBGE; 2015. [cited 2016 Nov 20]. Available 
from: http://www.ibge.gov.br/home/ estatistica/populacao/estimativa2015/ estimativa_dou.shtm

15. Couto MT, Pinheiro TF, Valença $O$, Machin R, Silva GSN, Gomes R, et al. $O$ homem na atenção primária à saúde: discutindo (in)visibilidade a partir da perspectiva de gênero. Interface. 2010;14:257-70.

16. Figueiredo W. Assistência à saúde dos homens: um desafio para os serviços de atenção primária. Cien Saude Colet. 2005;10:105-9.

17. Figueiredo WS. Masculinidade e cuidado: diversidade e necessidades de saúde dos homens na atenção primária [tese]. São Paulo: Faculdade de Medicina da Universidade de São Paulo; 2008.

18. Gomes R, Nascimento EF, Araújo FC. Por que os homens buscam menos os serviços de saúde do que as mulheres? As explicações de homens com baixa escolaridade e homens com ensino superior. Cad Saude Publica. 2007;23:565-74.

19. Madureira PR, Capitani EM, Campos GW S. Avaliação da qualidade da atenção à saúde na rede básica. Cad Saude Publica. 1989;5(1):45-59.

20. Rouquayrol MZ, Almeida N Fo. Epidemiologia e saúde. Rio de Janeiro: Guanabara Koogan; 2003.
21. Aldrigue RFT, Correr CJ, Melchiors AC, Pontarolo R. Análise da Completude de Prescrições Médicas Dispensadas em uma Farmácia Comunitária de Fazenda Rio Grande -Paraná (Brasil). Lat Am J Pharm. 2006;25:454-9.

22. Fröhlich SE. Aspectos da prescrição e da qualidade do uso de medicamentos no Programa de Saúde da Família [dissertação]. Porto Alegre: Faculdade de Farmácia da Universidade Federal do Rio Grande do Sul; 2006.

23. Obreli-Neto P, Prado M, Vieira J, Fachini F, Pelloso S, Marcon S, et al. Fatores interferentes na taxa de adesão à farmacoterapia em idosos atendidos na rede pública de saúde do Município de Salto Grande - SP, Brasil. Rev Cienc Farm Basica Apl. 2010;31:229-33.

24. World Health Organization. How to investigate drug use in health facilities: selected drug use indicators. Geneva: WHO; 1993. [cited 2016 Nov 25]. Available from: http://apps.who.int/ medicinedocs/en/d/Js2289e/

25. Girotto E, Silva PV. A prescrição de medicamentos em um município do Norte do Paraná. Rev Bras Epidemiol. 2006;9:226-34.

26. Laste G, Torres ILS, Deitos A, Souza AC, Souza A, Kauffmann C, et al. Análise de prescrições médicas dispensadas em farmácia no Sistema Único de Saúde. Rev HCPA. 2013;33:15-25.
27. Portela AS, Silva PCD, Simões MOS, Medeiros ACD, Montenegro AN No. Indicadores de prescrição e de cuidado ao paciente na atenção básica do município de Esperança, Paraíba, 2007. Epidemiol Serv Saude. 2012;21:341-50.

28. de Souza JM, Vinholes ER, Trauthman SC, Galato D. Avaliação dos indicadores de prescrição e da demanda atendida de medicamentos no Sistema Único de Saúde de um município do Sul do Estado de Santa Catarina. Rev Cienc Farm Basica Apl. 2012;33:107-13.

29. Cedeno AMR, Vazquez PMN, Leon JRF, Enríquez MQ. Determinación de polifarmacoterapia en pacientes geriátricos de un consultorio del médico de la familia en Cienfuegos. Rev Cub Farm. 2000;34:170-4.

30. Werder SF, Preskorn SH. Managing polypharmacy: walking the fine line. Curr Psychiatr. 2003;2:24-36.

31. Remondi FA, Cabrera MAS, Souza RKT. Não adesão ao tratamento medicamentoso contínuo: prevalência e determinantes em adultos de 40 anos e mais. Cad Saude Publica. 2014;30:126-36.

32. Vieira FS. Possibilidades de contribuição do farmacêutico para a promoção da saúde. Cien Saude Colet. 2007;12:213-20. 